Research Article

\title{
Antidiabetic activity of Plumeria rubra $L$. in normal and alloxan induced diabetic mice
}

\author{
Amruta V. Yadav', Vaishali R. Undale ${ }^{1}$, Ashok V. Bhosale ${ }^{3}$
}

\begin{abstract}
${ }^{1}$ Department of Pharmacology, SGRS College of Pharmacy, Saswad, Pune, Maharashtra, India

${ }^{2}$ Department of Pharmacology, Allana College of Pharmacy, Pune, Maharashtra, India ${ }^{3}$ Department of Pharmaceutics, SGRS College of Pharmacy, Saswad, Pune, Maharashtra, India
\end{abstract}

Received: 11 March 2016

Accepted: 15 April 2016

*Correspondence to: Dr. Vaishali R. Undale, Email: vaishaliundale @ gmail.com

Copyright: (C) the author(s), publisher and licensee Medip Academy. This is an openaccess article distributed under the terms of the Creative Commons Attribution NonCommercial License, which permits unrestricted noncommercial use, distribution, and reproduction in any medium, provided the original work is properly cited.

\begin{abstract}
Background: Diabetes mellitus is a major source of morbidity in developed countries. In spite of the introduction of hypoglycemic agents, diabetes and related complications continue to be a major medical problem. Our present study aims to investigate the antidiabetic activity of aqueous extract of plumeria rubra (PR) in experimental animals.
\end{abstract}

Methods: PR extract was subjected to antidiabetic study in alloxan induced diabetic model at three-dose levels 100,200 and $400 \mathrm{mg} / \mathrm{kg}$ respectively. It was also tested for hypoglycemic activity at same dose levels. Diabetes was induced by alloxan monohydrate $(150 \mathrm{mg} / \mathrm{kg}$, i.p.). PR extracts and standard drug glibenclamide $(10 \mathrm{mg} / \mathrm{kg}$, p.o.) was administered to animals for 28 days. The blood glucose, serum cholesterol, serum triglyceride, high density lipoprotein, low density lipoprotein, glycosylated hemoglobin. Body weights were assessed in the experimental animals. Histopathological observations during 28 days treatment were also evaluated.

Results: PR extract induced significant reduction $(\mathrm{P}<0.001)$ in fasting blood glucose levels in normal and alloxan-induced diabetic mice. Significant differences were observed in serum lipid profiles, glycosylated haemoglobin by extract treated-diabetic animals, when compared with the diabetic control and normal animals. The protective effect of PR was also evident from the histopathological examination on pancreas, liver and kidney. It reduced the injuries induced by alloxan.

Conclusions: PR exhibited significant antihyperglycemic activity in normal and alloxan-induced diabetic mice. The results of the present study provide support to the traditional usage of the plant in diabetes.

Keywords: Alloxan, Antidiabetic activity, Plumeria rubra

\section{INTRODUCTION}

Diabetes mellitus is a group of syndromes characterized by hyperglycaemia, altered metabolism of lipids, carbohydrates and proteins and an increased risk of complications from vascular diseases. ${ }^{1}$ It is a chronic disease caused by inherited or acquired deficiency in insulin secretion and by decreased responsiveness of the organs to secreted insulin. ${ }^{2}$ Such a deficiency results in increased concentrations of glucose in the blood, which in turn damage many of the body systems, in particular the blood vessels and nerves. ${ }^{3}$ It is currently growing at a rapid rate throughout the world, and it is the 16th leading cause of global mortality. ${ }^{4}$

Different types of oral hypoglycaemic agents are available along with insulin for the treatment of diabetes; there is an increased demand by patients to use natural 
products with antidiabetic activity. Since time immemorial, patients with non-insulin dependent diabetes have been treated orally in folk medicine, with a variety of plant extracts. In India, a number of plants are mentioned in ancient literature for the treatment of diabetic conditions. ${ }^{5}$

In the present study we have investigated the antidiabetic activity of aqueous extract of flowers of plumeria rubra (PR) in laboratory animals. The decoction of the flowers has been traditionally used by the Mexican people for treating diabetes mellitus. ${ }^{6,7}$ Phytochemical investigation of PR reveals the presence of flavonoids, tannins. ${ }^{8}$ These principles are known to be bioactive for the management of diabetes. ${ }^{9,10}$ Flavonoids exhibit hypoglycaemic activity and are also known for their ability of beta cell regeneration of pancreas. ${ }^{11-13}$

\section{METHODS}

\section{Collection and authentication of plant material}

PR flowers were collected fresh from the garden of Pune University in the month of October. Authentification of plant material was done at the Botanical Survey of India, Pune. The vouchure Specimen No. given was AMRPLR1.

\section{Extraction and preliminary phytochemical evaluation}

The flowers were separated, dried and powdered in grinder. The $60 \mathrm{~g}$ powder was extracted with $1000 \mathrm{ml}$ of boiling water for $30 \mathrm{~min}$. The resulting extract was dried under room temperature. The percentage yield obtained was $16.6 \%$. Resulted extract was collected and stored at room temperature. The extract was screened for the presence or absence of secondary metabolites such as alkaloids, flavonoids, tannins, glycosides using standard procedures. $^{14}$

\section{Animals}

Albino mice of either sex weighing 18-22 gm were used for the study. The animals were procured from the animal house of Seth Govind Raghunath Sable College of Pharmacy, Saswad, Maharashtra, India. Protocol of the experiments and animal usage were discussed in the institutional ethical committee meeting and permission was obtained to carry out the parameters selected for the study. Animals were housed individually in polypropylene cages, maintained under standard conditions (12-hours light and 12-hours dark cycle; $25 \pm 5^{\circ} \mathrm{C} ; 35-60 \%$ humidity), the animals were fed with standard pellet diet and provided water ad libitum.

\section{Acute toxicity study}

Acute oral toxicity was carried out according to OECD guidelines 425. Albino mice (female) weighing between
25 to $40 \mathrm{~g}$ was used. Above study was done at dose 2000 $\mathrm{mg} / \mathrm{kg}$ and $5000 \mathrm{mg} / \mathrm{kg}$ body weight. ${ }^{15}$

\section{Assessment of PR extract in normal fasted mice}

For the normoglycemic study, mice were divided into five groups $(n=6)$ and were administered distilled water, glibenclamide $(10 \mathrm{mg} / \mathrm{kg}), \mathrm{PR}$ extract $100,200,400$ $\mathrm{mg} / \mathrm{kg}$ respectively. The blood glucose levels were measured at $0,1,2,4,8,12$ hours after drug administration.

Assessment of PR extract in alloxan induced diabetic mice

Diabetes was induced by a single i.p. injection of freshly prepared $150 \mathrm{mg} / \mathrm{kg}$ of alloxan monohydrate in sterile saline. After $48 \mathrm{~h}$ of alloxan injection, the diabetic mice (glucose level $>250 \mathrm{mg} / \mathrm{dl}$ ) were used for the study. The animals are divided into following groups, each containing 6 mice. $^{16-18}$

\section{Experimental design}

Group I- received distilled water (D.W.)

Group II- received glibenclamide $(10 \mathrm{mg} / \mathrm{kg})$

Group III- received PR extract (100 mg/kg p.o.)

Group IV- received PR extract (200 mg/kg p.o.)

Group V- received PR extract (400 mg/kg p.o.)

Blood samples were withdrawn from all animals on $0,3^{\text {rd }}$, $7^{\text {th }}, 14^{\text {th }}, 21^{\text {st }}, 28^{\text {th }}$ day in animals by tail vein puncture method and BG was estimated by one touch horizon glucometer strips. Change in blood glucose, mean and SEM were calculated and tabulated.

\section{Histopathological study}

Pancreas, liver, kidney were removed, stored in $10 \%$ formalin and then processed with varying grades of alcohol followed by xylene and paraffin. Tissues were embedded in paraffin and cut at 5 micron using microtome and stained after deparrination using hematoxylin and eosin stains to verify morphological assessment. Microscopic analysis was done.

\section{Statistical analysis}

The results were expressed as mean \pm SEM. Comparison between the groups was made by one-way analysis of variance (ANOVA) followed by "Dunnett's test". $\mathrm{P}<0.05$ was considered to be significant.

\section{RESULTS}

\section{Effect of PR extract on acute toxicity study}

Acute toxicity studies revealed the nontoxic nature of the aqueous extract of PR. There were no lethality or toxic reactions found till dose of $5000 \mathrm{mg} / \mathrm{kg}$ until the end of the 
study period. All the animals were alive, healthy, and active during the observation period.

\section{Preliminary phytochemical evaluation}

The preliminary phytochemical screening of the aqueous extract showed the presence of alkaloids, flavonoids, tannins.
Effect of PR extract on blood glucose level in normal and diabetic mice, body weight and lipid profile of diabetic mice

Table 1 shows the mean \pm SEM blood glucose values at the intervals of $0,1,2,4,8,12$ hours respectively. In normal animals, significant $(\mathrm{P}<0.001)$ reduction in the blood glucose level was observed by the aqueous extract as compared to the control.

Table 1: Effect of PR extract on blood glucose level in normal mice.

\begin{tabular}{|llllllll|}
\hline Groups & $\begin{array}{l}\text { Dose } \\
\mathbf{m g} / \mathrm{kg}\end{array}$ & $\begin{array}{l}\mathbf{0} \text { hour } \\
(\mathbf{m g} / \mathbf{d l})\end{array}$ & $\begin{array}{l}\mathbf{1} \text { hour } \\
(\mathbf{m g} / \mathbf{d l})\end{array}$ & $\begin{array}{l}\mathbf{2} \text { hours } \\
(\mathbf{m g} / \mathbf{d l})\end{array}$ & $\begin{array}{l}\mathbf{4} \text { hours } \\
(\mathbf{m g} / \mathbf{d l})\end{array}$ & $\begin{array}{l}\mathbf{8} \text { hours } \\
(\mathbf{m g} / \mathbf{d l})\end{array}$ & $\begin{array}{l}\mathbf{1 2} \text { hours } \\
(\mathbf{m g} / \mathbf{d l})\end{array}$ \\
\hline $\begin{array}{l}\text { Normal } \\
\text { control }\end{array}$ & vehicle & $90.83 \pm 1.515$ & $91.33 \pm 1.726$ & $103.8 \pm 1.014$ & $96.00 \pm 1.23$ & $95.50 \pm 1.28$ & $97.67 \pm 1.52$ \\
\hline $\begin{array}{l}\text { Gliben- } \\
\text { clamide }\end{array}$ & 10 & $90.67 \pm 1.38$ & $77.53 \pm 0.87^{* * *}$ & $71.50 \pm 1.17^{* * *}$ & $76.50 \pm 1.43^{* * *}$ & $77.67 \pm 1.22^{* * *}$ & $76.8 \pm 1.44^{* * *}$ \\
\hline PR & 100 & $90.17 \pm 1.60$ & $86.00 \pm 0.73^{* *}$ & $85.87 \pm 2.00^{* * *}$ & $81.67 \pm 1.52^{* * * *}$ & $82.67 \pm 1.22^{* * * *}$ & $85.00 \pm 0.96^{* * *}$ \\
\hline PR & 200 & $91.91 \pm 2.07$ & $83.67 \pm 0.61^{* * *}$ & $80.83 \pm 2.34^{* * *}$ & $75.83 \pm 1.44^{* * *}$ & $73.17 \pm 1.13^{* * *}$ & $71.83 \pm 1.01^{* * * *}$ \\
\hline PR & 400 & $93.4 \pm 1.63$ & $85.67 \pm 0.55^{* *}$ & $84.00 \pm 1.39^{* * *}$ & $80.67 \pm 1.52^{* * * *}$ & $82.50 \pm 0.99^{* * *}$ & $80.67 \pm 1.96^{* * *}$ \\
\hline
\end{tabular}

Values are expressed as mean \pm S.E.M $(\mathrm{n}=6)$. $* \mathrm{P}<0.05, * * \mathrm{P}<0.01$, $* * * \mathrm{P}<0.001$ when compared with control (ANOVA followed by Dunnet's test).

Table 2: Effect of PR extract on blood glucose level in diabetic mice.

\begin{tabular}{|llllllll|}
\hline Groups & $\begin{array}{l}\text { Dose } \\
(\mathbf{m g} / \mathbf{k g})\end{array}$ & $\begin{array}{l}\text { Day 0 } \\
(\mathbf{m g} / \mathbf{d l})\end{array}$ & $\begin{array}{l}\text { Day 3 } \\
(\mathbf{m g} / \mathbf{d l})\end{array}$ & Day 7(mg/dl) & $\begin{array}{l}\text { Day 14 } \\
(\mathbf{m g} / \mathbf{d l})\end{array}$ & $\begin{array}{l}\text { Day 21 } \\
(\mathbf{m g} / \mathbf{d l})\end{array}$ & $\begin{array}{l}\text { Day 28 } \\
(\mathbf{m g} / \mathbf{d l})\end{array}$ \\
\hline $\begin{array}{l}\text { Diabetic } \\
\text { control }\end{array}$ & vehicle & $94.17 \pm 2.56$ & $320.5 \pm 3.83$ & $325.5 \pm 3.67$ & $326.3 \pm 3.92$ & $318.0 \pm 3.05$ & $317.7 \pm 2.89$ \\
\hline $\begin{array}{l}\text { Gliben- } \\
\text { clamide }\end{array}$ & 10 & $95.67 \pm 2.66$ & $315.7 \pm 22.24$ & $280 . \pm 2.01 * * *$ & $181.0 \pm 4.48 * * *$ & $142.0 \pm 4.84 * * *$ & $100.7 \pm 3.61 * * *$ \\
\hline PR & 100 & $96.33 \pm 2.57$ & $316.8 \pm 2.38$ & $291.3 \pm 2.12 * * *$ & $230.7 \pm 2.40 * * *$ & $166.3 \pm 2.60 * * *$ & $129.7 \pm 3.77 * * *$ \\
\hline PR & 200 & $95.67 \pm 2.84$ & $317.0 \pm 2.17$ & $288.0 \pm 2.09 * * *$ & $200.5 \pm 2.48^{* * *}$ & $156.0 \pm 6.87 * * *$ & $118.2 \pm 3.39 * * *$ \\
\hline PR & 400 & $94.83 \pm 2.89$ & $317.3 \pm 2.18$ & $290.7 \pm 1.97 * * *$ & $221.2 \pm 2.35^{* * *}$ & $161.7 \pm 4.60 * * *$ & $128.0 \pm 2.53 * * *$ \\
\hline
\end{tabular}

Values are expressed as mean \pm S.E.M $(\mathrm{n}=6) . * \mathrm{P}<0.05 * * \mathrm{P}<0.01 * * * \mathrm{P}<0.001$ when compared with diabetic group (ANOVA followed by Dunnet's test).

Table 2 shows the mean \pm SEM blood glucose values at the intervals of $0,3,7,14,21,28$ day respectively. Glibenclamide and PR extract treated group $(100,200,400$ $\mathrm{mg} / \mathrm{kg})$, showed significant reduction $(\mathrm{P}<0.001)$ from $7^{\text {th }}$ to $28^{\text {th }}$ day. In DC group, the elevated blood glucose levels were maintained throughout the 30 days of treatment period indicating that the mice were rendered diabetic.

Table 3: Effect of PR extract on body weight in alloxan induced diabetic mice.

\begin{tabular}{|lllllll|}
\hline Groups & Dose $(\mathbf{m g} / \mathrm{kg})$ & Day 0 $(\mathbf{m g})$ & Day 7 $(\mathbf{m g})$ & Day 14 $(\mathbf{m g})$ & Day 21 $(\mathbf{m g})$ & Day 28 $(\mathbf{m g})$ \\
\hline NC & Vehicle & $29.83 \pm 1.57$ & $30.00 \pm 1.50$ & $30.67 \pm 1.35$ & $31.00 \pm 1.21$ & $32.00 \pm 1.12 * * *$ \\
\hline DC & Vehicle & $28.17 \pm 1.30$ & $28.00 \pm 1.82$ & $27.00 \pm 1.82$ & $25.50 \pm 2.32$ & $23.83 \pm 1.27$ \\
\hline Glibenclamide & 10 & $28.83 \pm 1.44$ & $28.17 \pm 1.30$ & $29.50 \pm 1.28$ & $29.33 \pm 1.80$ & $30.50 \pm 1.43 * *$ \\
\hline PR & 100 & $28.67 \pm 1.22$ & $27.67 \pm 1.22$ & $27.17 \pm 1.74$ & $27.83 \pm 1.44$ & $27.67 \pm 1.08$ \\
\hline PR & 200 & $29.00 \pm 1.39$ & $27.50 \pm 1.47$ & $28.00 \pm 1.65$ & $27.83 \pm 1.44$ & $28.50 \pm 0.99$ \\
\hline PR & 400 & $28.83 \pm 1.30$ & $27.67 \pm 1.35$ & $27.50 \pm 1.43$ & $27.83 \pm 2.02$ & $27.50 \pm 1.60$ \\
\hline
\end{tabular}

Values are expressed as mean \pm S.E.M $(\mathrm{n}=6)$. $* \mathrm{P}<0.05 * * \mathrm{P}<0.01 * * * \mathrm{P}<0.001$ when compared with diabetic group (ANOVA followed by Dunnet's test). 
Table 3 shows the changes in body weight of diabetic mice. In the control treated group, significant increase $(\mathrm{P}<0.001)$ was seen on day 28 , while Glibenclamide $(10$ $\mathrm{mg} / \mathrm{kg})$, treated group showed increase $(\mathrm{P}<0.01)$ on day 28. No significant changes were observed in the test group.

Table 4: Effect of PR extract on lipid profile.

\begin{tabular}{|lllllll|} 
Groups & Dose $\mathrm{mg} / \mathrm{kg}$ & $\mathrm{TG}(\mathrm{mg} / \mathrm{dl})$ & $\mathrm{TC}(\mathrm{mg} / \mathrm{dl})$ & HDL $(\mathrm{mg} / \mathrm{dl})$ & $\mathrm{LDL}(\mathrm{mg} / \mathrm{dl})$ & VLDL $(\mathrm{mg} / \mathrm{dl})$ \\
\hline NC & vehicle & $34.66 \pm 1.58^{* *}$ & $50.83 \pm 2.16^{* *}$ & $23.33 \pm 0.66^{* * *}$ & $20.57 \pm 2.84^{* *}$ & $6.93 \pm 0 . .31^{* * *}$ \\
\hline DC & vehicle & $45.00 \pm 2.32$ & $61.83 \pm 1.01$ & $15.30 \pm 0.60$ & $33.83 \pm 1.40$ & $9 \pm 0.46$ \\
\hline $\begin{array}{l}\text { Gliben- } \\
\text { clamide }\end{array}$ & 10 & $31.83 \pm 1.40^{* * *}$ & $50.66 \pm 1.82^{* *}$ & $22.33 \pm 0.61^{* * *}$ & $21.97 \pm 1.73^{* *}$ & $6.36 \pm 0.28^{* * *}$ \\
\hline PR & 100 & $34.5 \pm 1.38^{* *}$ & $53.33 \pm 2.36^{*}$ & $19.83 \pm 0.47^{* * *}$ & $26.60 \pm 2.70$ & $6.90 \pm 0.27^{* * * *}$ \\
\hline PR & 200 & $33.17 \pm 1.16^{* * *}$ & $52.5 \pm 2.34^{*}$ & $21.16 \pm 0.60^{* * *}$ & $24.70 \pm 2.52^{*}$ & $6.63 \pm 0.23^{* *}$ \\
\hline PR & 400 & $34.16 \pm 1.27^{* *}$ & $52.33 \pm 2.18^{*}$ & $20.16 \pm 0.70^{* * *}$ & $25.33 \pm 1.79^{*}$ & $6.83 \pm 0.25^{* * *}$ \\
\hline
\end{tabular}

Values are expressed as mean \pm S.E.M $(\mathrm{n}=6)$. $* \mathrm{P}<0.05 * * \mathrm{P}<0.01 * * * \mathrm{P}<0.001$ when compared with diabetic group (ANOVA followed by Dunnet's test)

Table 4 shows the changes in lipid profile of diabetic mice. In glibenclamide $(10 \mathrm{mg} / \mathrm{kg})$ treated groups, significant decrease $(\mathrm{P}<0.001)$ was seen in $\mathrm{TG}$, HDL and VLDL. TC, LDL also showed significant decrease $(\mathrm{P}<0.01)$ as compared to diabetic control.

PR $(100 \mathrm{mg} / \mathrm{kg})$ showed reduction in TG $(\mathrm{P}<0.01)$, TC $(\mathrm{P}<0.05)$, HDL $(\mathrm{P}<0.001)$ and VLDL $(\mathrm{P}<0.001)$ levels as compared to DC. PR $(200 \mathrm{mg} / \mathrm{kg})$ showed reduction in TG $(\mathrm{P}<0.001)$, TC $(\mathrm{P}<0.05)$, HDL $(\mathrm{P}<0.001)$, LDL $(\mathrm{P}<0.05)$, VLDL $(\mathrm{P}<0.001)$. PR $(400 \mathrm{mg} / \mathrm{kg})$ showed reduction in TG $(\mathrm{P}<0.01)$, TC $(\mathrm{P}<0.05)$, HDL $(\mathrm{P}<0.001)$, LDL $(\mathrm{P}<0.05)$, VLDL $(\mathrm{P}<0.001)$.

\section{Histopathology of pancreas}
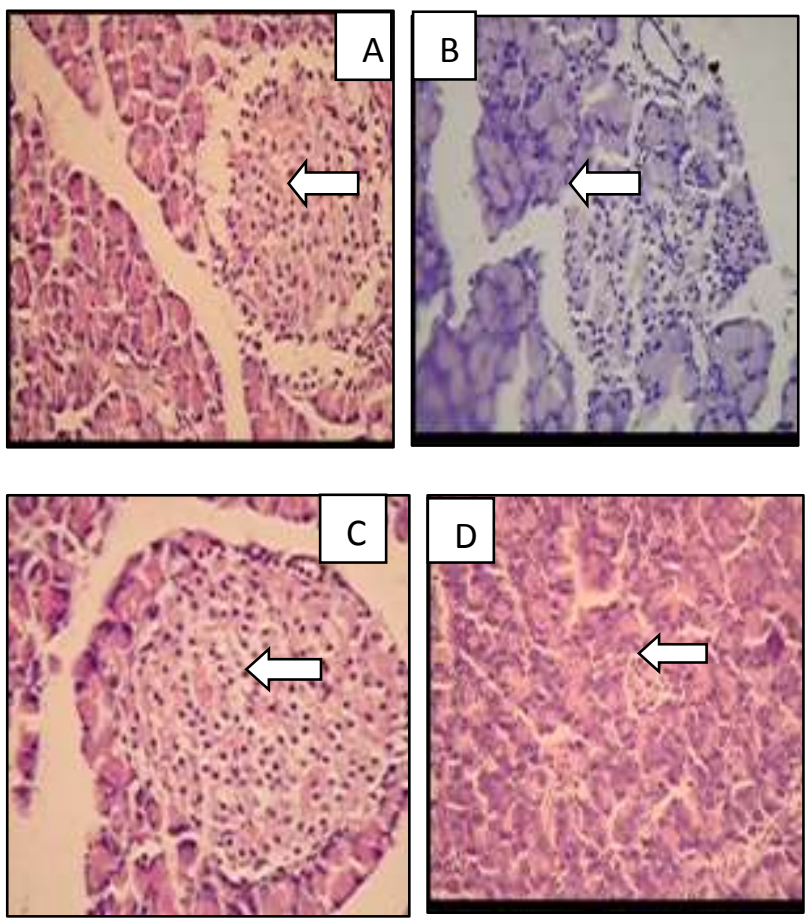
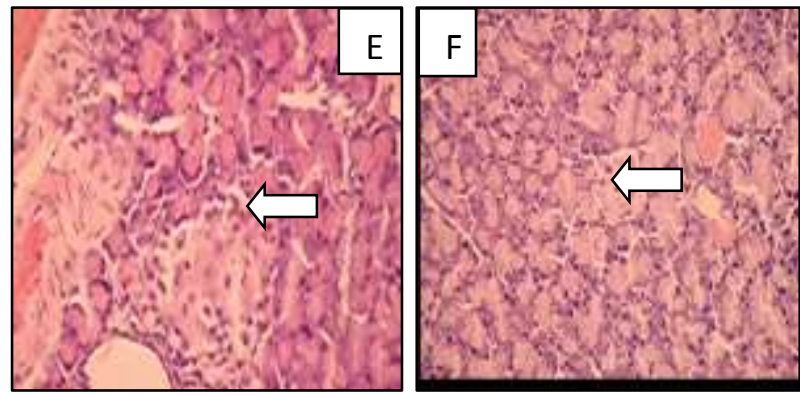

Figure 1: Effect of PR extract on histopathological studies; (A) NC; (B) DC; (C) glibenclamide (10 $\mathrm{mg} / \mathrm{kg})$; (D) PR (100 mg/kg); (E) PR (200 mg/kg); (F) PR (400 mg/kg).
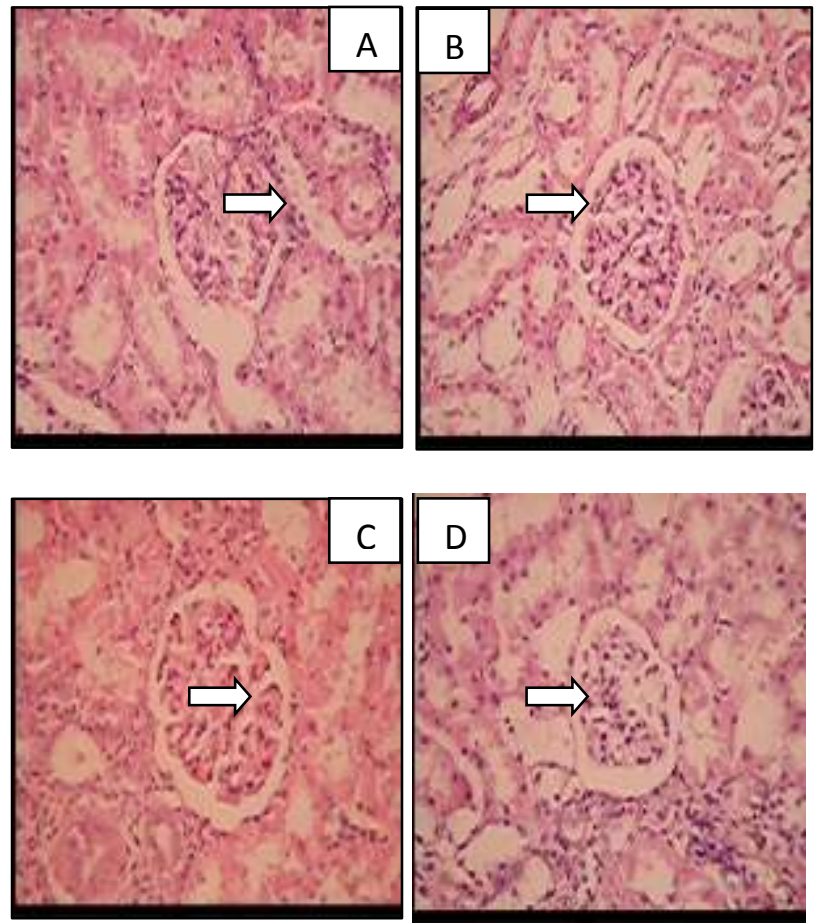

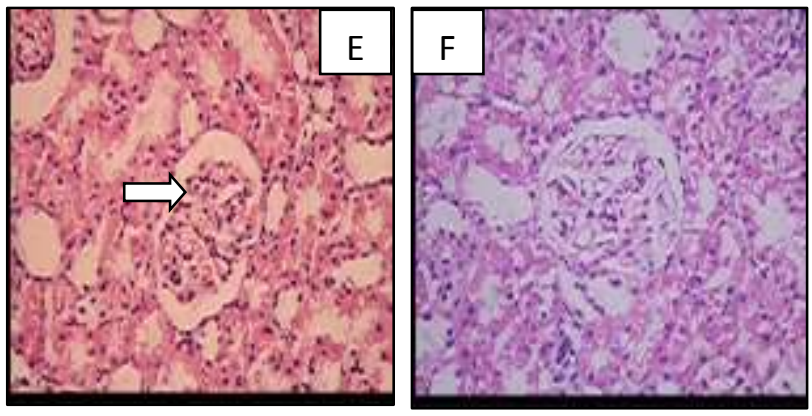

Figure 2: Effect of PR extract on histopathology of kidney; (A) NC; (B) DC; (C) glibenclamide (10 mg/kg); (D) PR (100 mg/kg); (E) PR (200 mg/kg); (F) PR (400 mg/kg).
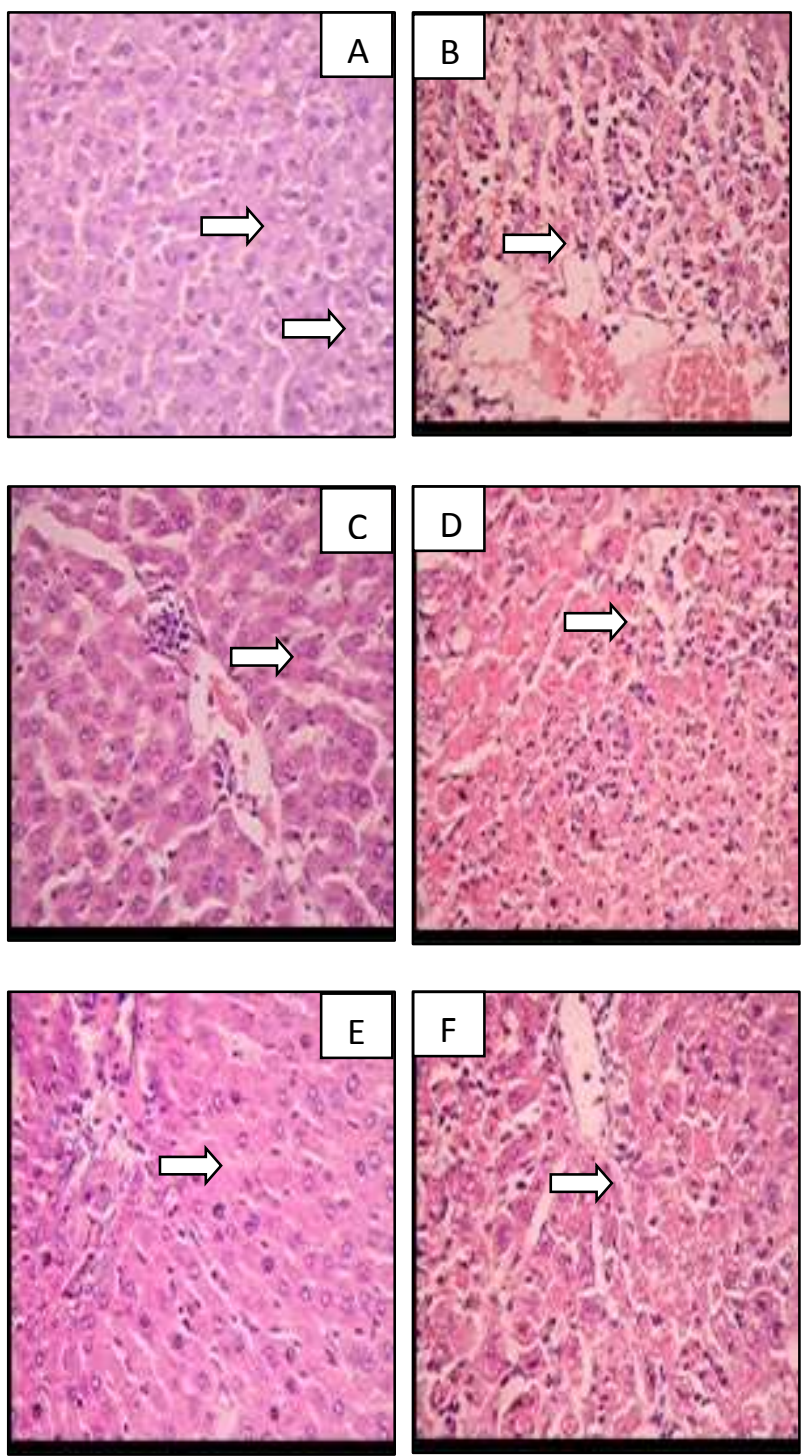

Figure 3: Effect of PR extract on histopathology of kidney; (A) NC; (B) DC; (C) glibenclamide (10 $\mathrm{mg} / \mathrm{kg}$ ); (D) PR (100 mg/kg); (E) PR (200 mg/kg); (F) PR (400 mg/kg).

\section{DISCUSSION}

In light of the results, our study indicates that aqueous extract of PR exhibited significant anti-hyperglycaemic activity in normal and alloxan-induced diabetic mice. Effective blood glucose control is the key for preventing or reversing diabetic complications and improving the quality of life in patients with diabetes. Thus, sustained reduction in hyperglycaemia will decrease the risk of developing microvascular complications and most likely reduce the risk of macro vascular complications. Alloxan induces diabetes by destroying B cells of pancreas, through production of reactive oxygen species. Our investigations indicate the efficiency of the plant extract in the maintenance of blood glucose levels in normal and alloxan induced diabetic mice.

The levels of serum lipids are usually elevated in diabetes mellitus and such an elevation represents a risk factor for coronary heart disease. This abnormally high level of serum lipids is mainly due to the uninhibited actions of lipolytic hormones on the fat depots, mainly due to the action of insulin. Under normal circumstances, insulin activates the enzyme lipoprotein lipase, which hydrolyses triglycerides. However, in diabetic state, lipoprotein lipase is not activated due to insulin deficiency, resulting in hypertriglyceridemia and insulin deficiency is also associated with hypercholesterolemia due to metabolic abnormalities. ${ }^{19}$ Regular administration of the aqueous extract of PR nearly normalized lipid profile in diabetic animals. It not only lowered TC, TG and LDL but also enhanced the cardio protective lipid HDL. Decrease in the body weight was arrested by PR which was precise in alloxan induced diabetic mice.

The protective effect of PR is also evident from the histopathological examination on pancreas, liver and kidney. It evidently reduced the injuries of pancreas, kidney, liver induced by alloxan. From this study we can conclusively state that PR aqueous extract has shown remarkable effects on blood glucose level and marked improvement on hyperlipidemia due to diabetes. Its specific effect on HDL has additional advantage in checking coronary risks. The extract seems to have no toxicity as no death is reported up to 10 times of effective dose. This anti-hyperglycaemic effect of PR extract suggests that its main mechanism may be mediated through the interaction between insulin and gluconeogenesis, which further affects glucose metabolism in the liver and other tissues in the body, and introduces abnormal or disordered glucose metabolism to normal or ordered. Further pharmacological and biochemical investigations are underway to elucidate the detailed mechanism of the antidiabetic and hypolipidemic effect of the plant.

\section{Funding: No funding sources \\ Conflict of interest: None declared}

Ethical approval: The study was approved by the Institutional Ethics Committee 


\section{REFERENCES}

1. Davis SN. Insulin, oral hypoglycemic agents and the pharmacology of the endocrine pancreas. Goodman and Gilmans the Pharmacological Basis of Therapeutics. Brunton, L.L. (Ed.). McGraw-Hill. New York; 2006:1613-45.

2. Matsui T, Tanaka T, Tamura S, Toshima A. Alpha glucosidase inhibitory profile of catechins and theaflavins. J Agric Food Chem. 2007;55:99-105.

3. Nagappa AN, Thakurdesai PA, Rao NV, Singh J. Antidiabetic activity of terminalia catappa linn fruits. Journal of Ethnopharmacology. 2008;88:45-50.

4. Murray CJ, Lopez AD. Mortality by cause for eight regions of the world. global burden of disease study. Lancet. 1997;349:1269-76.

5. Jarald EE, Joshi SB, Jain DC. Antidiabetic activity of flower buds of michelia champaca Linn. 2008;40:256-60.

6. Jarald EE, Joshi SB, Jain DC. Diabetes and herbal medicines. Iranian Journal of Pharmacology and Therapeutics. 2008;97-106.

7. Galicia EH, Contreras AA, Santamaria LA, Ramos RR, Miranda AA, Vega LM, et al. Studies on hypoglycemic activity of Mexican medicinal plants. proc. West Pharmacol Soc. 2002;45:118-24.

8. Medicinal plants in the south pacific. WHO Regional publications. 1998;19:151.

9. Coskun O, Kanter M, Korkmaz A, Oter S. Quercetin, a flavonoid antioxidant, prevent and protects streptozotocin-induced oxidative stress and-cell damage in rat pancreas. Pharmacological Research. 2005;51:117-123.

10. Marles RJ, Farnsworth NR, Antidiabetic plants and their active constituents. Phytomedicine. 1995;2:137-189.
11. Ahmad M, Akhtar MS, Malik T, Gilani AH. Hypoglycemic actionof flavonoids fraction of cuminum nigrum seeds. Phytotherapy Research. 2000;14:03-106.

12. Pathak D, Pathak K, Singla AK. Flavonoids as medicinal agents recent advances. Fitoterapia. 1991;62:371-89.

13. Chakravarti BK, Gupta S, Gambhir SS, Gode KD. Pancreatic betacell regeneration. A novel antidiabetic mechanism of Pterocarpusmarsupium Roxb. Indian Journal of Pharmacology. 1980;12:123-27.

14. Kokate CK, Purohit AP, Gokhale SB. Text book of pharmacognosy. $33^{\text {rd }}$ ed. Pune; Nirali Prakashan; 2001.

15. OECD 2001. Acute oral toxicity up and down procedure. OECD guidelines for the testing of chemicals 425 . Available at http://iccvam.niehs.nih.gov/SuppDocs/FedDocs/OEC D/OECDtg425.pdf.

16. Venkatesh S, Reddy GD, Reddy BM, Ramesh M, Appa Rao AV. Antihyperglycemic activity of Caralluma attenuata. Fitoterpia. 2003;74:274-9.

17. Sun JE, Ao ZH, Lu JM, Xu Z, Zhang XM, Dou WF. Antihyperglycemic and antilipidperoxidative effects of dry matter of culture broth of innonotus obliquus in submerged culture on normal and alloxan diabetes mice. Journal of Ethnopharmacology. 2008;118:7-13.

18. Verma PK, Gaikwad NJ. Hypoglycemic activity of cephalandra indica naud stems. Adv Pharmacol Toxicol. 2006;7:57-60.

19. Vijay S, Patel V, Chitra P, Prasanna PL, Krishnaraju V. Hypoglycemic effect of aqueous extract of parthenium hysterophorus L. in normal and alloxan induced diabetic rats. Indian Journal of Pharmacology. 2008;40:183-5.

Cite this article as: Yadav AV, Undale VR, Bhosale AV. Antidiabetic activity of Plumeria rubra $L$. in normal and alloxan induced diabetic mice. Int J Basic Clin Pharmacol 2016;5:884-9. 